\title{
MEMBERSIHKAN MASJID AL-IKHLAS DUSUN PALLOLI DESA BONTOCINI
}

\author{
RATNASARI
}

9173770410258

\section{ratna.sarhyi@gmail.com}

1. Bentuk kegiatan

> Membersihkan Masjid baik dalam Masjid maupun halaman Masjid

2. Lokasi

Masjid Al-Ikhlas dusun Palloli desa Bontocini

3. Hari/Tanggal dan Waktu

Jum'at 25 September 2020 pukul 07:00 - selesai

4. Peserta Yang Dilibatkan

Mahasiswa KKLP Yapti Jeneponto

5. Alasan Diadakannya

Alasan diadakannya adalah karena melihat keadaan masjid yang terlihat kotor mengingat akan dilaksanakan sholat jum'at maka kami para Mahasiswa berinisiatif membersikan masjid tersebut.

6. Tujuan dan Manfaat

> Tujuan dan Manfaatnya adalah untuk membersihkan Masjid agar supaya masyarakat desa bontocinidapat beribadah dengan nyaman

7. Deskripsi Kegiatan

Kegiatan membersihkan masjid ini dilaksanakan pada pagi hari, sebelum dilaksanakannya sholat jum'at keadaan masjid sudah dalam keadaan bersih. Kegiatan ini melibatkan Mahasiswa KKLP Yapti Jeneponto sebagai pelaksana kegiatan. 